\title{
MULTI-CRITERIA ANALYSIS FOR SELECTING SUITABLE SITES OF WATER HARVESTING IN NORTHERN AL THARTHAR WATERSHED
}

\author{
RAID MAHMOOD FAISAL ${ }^{1 *}$ AND MOHAMMED ABDAKI ${ }^{2}$ \\ ${ }^{1}$ Department of Environmental Technology, College of Environmental Sciences \& Technology, Mosul University, 41002, \\ Mosul, Iraq. ${ }^{2}$ Department of Environmental Technology, College of Environmental Sciences \& Technology, Mosul University, \\ 41002, Mosul, Iraq.
}

*Corresponding author: raidalfaisal@uomosul.edu.iq

Submitted final draft: 28 July $2020 \quad$ Accepted: 23 September 2020

http://doi.org/10.46754/jssm.2021.10.017

\begin{abstract}
Water scarcity in Iraq is becoming a critical issue as demand increases, particularly in arid and semi-arid regions. In response, water harvesting $(\mathrm{WH})$ is a promising technique that can effectively catch surface runoff and thus it could cover different water needs and mitigate droughts. The study objective is to identify and select potential suitable sites for theerection of dams for water harvesting in the northern Al-Tharthar watershed. The study focuses on building an integrated GIS-based multi-criteria model and by using Analytic Hierarchy Process (AHP), where relative importance is obtained from (AHP) through use of ArcGIS 10.5. The model combines 7 Biophysical criterions including: slope, elevation, stream orders, annual rainfall, soil texture, land cover/land use, and runoff zones. However, 4 socio-economic criteria include: settlements and roads, population and rural density, agriculture density, and livestock water demand. Biophysical criteria importance weighted around $84.62 \%$ whereas socio-economic importance is $15.38 \%$ in the model. The final score for the degree of suitability is produced by using Raster Calculator, it includes 5 classes, from very high suitability to very low suitability. The results demonstrated that the middle and northern part has medium and higher degree of suitability for water harvesting. Furthermore, in the research area the medium and higher degree of suitability covers around $64.013 \%$ in contrast to $35.987 \%$ which is less suitable for water harvesting. Three potential dams have been identified as highly suitable with storage capacity from the first to the third $37,359,680.5 \mathrm{~m}^{3}, 76,273,409.9 \mathrm{~m}^{3}$ and $9,690,685.6 \mathrm{~m}^{3}$ respectively.
\end{abstract}

Keywords: Water harvesting, Iraq, GIS, multi-criteria, AHP.

\section{Introduction}

Water scarcity of freshwater has dramatically increased globally (Shadmehri et al., 2020). It is becoming a major threat in several countries, particularly in developing ones (Ibrahim et al., 2019). A possible suitable and sustainable alternative water resource for many activities could be harvested rainwater (Ibrahim et al., 2019). Harvesting could effectively capture the surface runoff. It is also a system which is used to collect precipitation around catchment periphery rather than release it as runoff (Hari et al., 2018). Building structures within the catchment to harvest income water, and therefore increase water availability, has become widely used in recent years and has become a success and acceptable practice, especially in arid and semi-arid regions (Adham et al., 2018).
Water harvesting (WH) structures act as a barrier to soil erosion, prevent flooding and ponds for farming (Hari et al., 2018). Among other considerations, local stakeholders prefer water harvesting techniques (Campisano et al., 2017). WH structures act as surface storage and can increase ecosystem productivity (Lloyd \& Dennison, 2018). There are ample advantages of using WH techniques in agriculture (Terêncio et al., 2018). such as reliable water source for livestock and provides a clean and renewable water resource (Sarzaeim et al., 2017).

The success of a water harvesting system heavily depends on selecting criteria and features of sites (Lee et al., 2016). Consequently, the main factors chosen for the model of site selection are extremely important and they will be the key to WH system success (Terêncio et al., 2018; Wu 
et al., 2018). The key role for the success of the water harvesting system is choosing optimal locations to use later in dry seasons. Appropriate site selection in large areas is a great challenge (Adham et al., 2018).

Delineation of possible sites for water harvesting by using an integrated model of different environmental variables and Geographic Information System (GIS) can provide very precise, accurate and powerful procedure for decision makers (Salman et al., 2017; Selamat et al., 2019). Optimal sites for $\mathrm{WH}$ and estimating of runoff in large areas are the greatest challenge (Inamdar et al., 2018). The technique of choosing suitable sites through GIS model is based on two different groups of criteria (Socio-economic and Biophysical). GIS can provide very important reliable and accurate information at large spatial scales to estimate and manage water resources (Sagar \& Chauhan, 2017). GIS has proven to be successful and is considered to be a robust scientific tool to deal with large multi-spatial data (Al-Jarjees, 2020; Parkinson et al., 2018). It's also an attractive, effective tool in selecting suitable sites for catchment water harvesting (Varade et al., 2017). Analytical Hierarchy Process (AHP) is a technique for multi-criteria analysis. Currently, many researchers depend on GIS and AHP in using multi-environmental criteria and spatial factors to select optimal zones of water collecting (Alkhatib et al., 2019). Combining GIS and AHP methods in selecting sites have shown highly accurare results (Wu et al., 2018). GIS-based multi-environmental criteria and AHP approach for assessing and selecting sites of water harvesting have become widely used. Integrated models can successfully choose the best possible sites for collecting water, on the other hand it can cope with challenges of missing some data (Haile \& Suryabhagavan, 2019).

Water shortage becomes a serious issue in arid and semi-arid regions (Alwan et al., 2020). In those regions' rainfall patterns are unpredictable in both quantity and frequency, thus measuring and managing produced runoff is very important. Water harvesting in arid and semi-arid regions has been introduced as an alternative approach which participated in an increase of water availability. Understanding the nature of the catchment regarding hydrological behaviour is the most important step to plan water harvesting strategy (Campisano et al., 2017)

Generally, Iraq is located in arid to semiarid zones, but it has unstable precipitation trends (Ibrahim et al., 2019). Until 1970, Iraq was classified as a country rich in water resources because of the Tigris and Euphrates rivers running through it (Adham et al., 2018). Water scarcity in Iraq became a critical issue after years of war lack of water policies and management. Moreover, a high proportion of its water discharges directly into the Gulf (Alwan et al., 2020). This one of the most promising techniques for increasing water availability in Iraq (Saleh et al., 2018).

Little attention has been paid on exploring the reliability of implementing water harvesting strategies in arid and semi-arid areas on large spatial scales (Campisano et al., 2017). No research has been done on this scale of criteria, and on socio-economic criteria. The aim of this study is to identify potential sites for water harvesting in northern Al-Tharthar watershed, through using integrated GIS-based model and AHP method, including a comprehensive multi biophysical, environmental and socioeconomics criteria analysis.

\section{Materials and Methods}

\section{Study Area}

Al-Tharthar valley catchment is one of the biggest watersheds in the Nineveh governorate the northwest desert of Iraq ( $\mathrm{H}$. Al-Ardeeni, 2018). The catchment includes the Tharthar lake (depression), which is located between the Euphrates and Tigris rivers (Rahi \& Halihan, 2018). The catchment is in arid and semi-arid zones with hot summers and cold winters $(\mathrm{H}$. Al-Ardeeni, 2018). The geographic location of the study area stretches from $35^{\circ} 17^{\prime} 45.4^{\prime \prime}$ to $36^{\circ} 31^{\prime} 7.7^{\prime \prime} \mathrm{N}$ latitude and from $41^{\circ} 52^{\prime} 20.4^{\prime \prime}$ to 
$43^{\circ} 03^{\prime} 7.3$ " E longitude. The catchment covers an area of $6135.77 \mathrm{~km}^{2}$ as shown in Figure 1.

The catchment is mostly dry all year, however, the rainy season triggers short concentrated floods (Adham et al., 2018). The mean monthly temperature varies from $33.9^{\circ} \mathrm{C}$ in summer to $7.8^{\circ} \mathrm{C}$ in winter. The annual average rainfall is less than $350 \mathrm{~mm}$. The majority of rainfall, about $49 \%$, occurs in winter, while rains in spring and autumn are at $36 \%$ and $15 \%$ respectively. The rainy season extends from November to April. The main water resource of the catchment is rainfall (Saleh et al., 2018) which is used for irrigation (Thair et al., 2017) and various agricultural activities, mainly cultivation of barley, wheat and ranching livestock (Al-Ozeer et al., 2020; H. Al-Ardeeni, 2018).
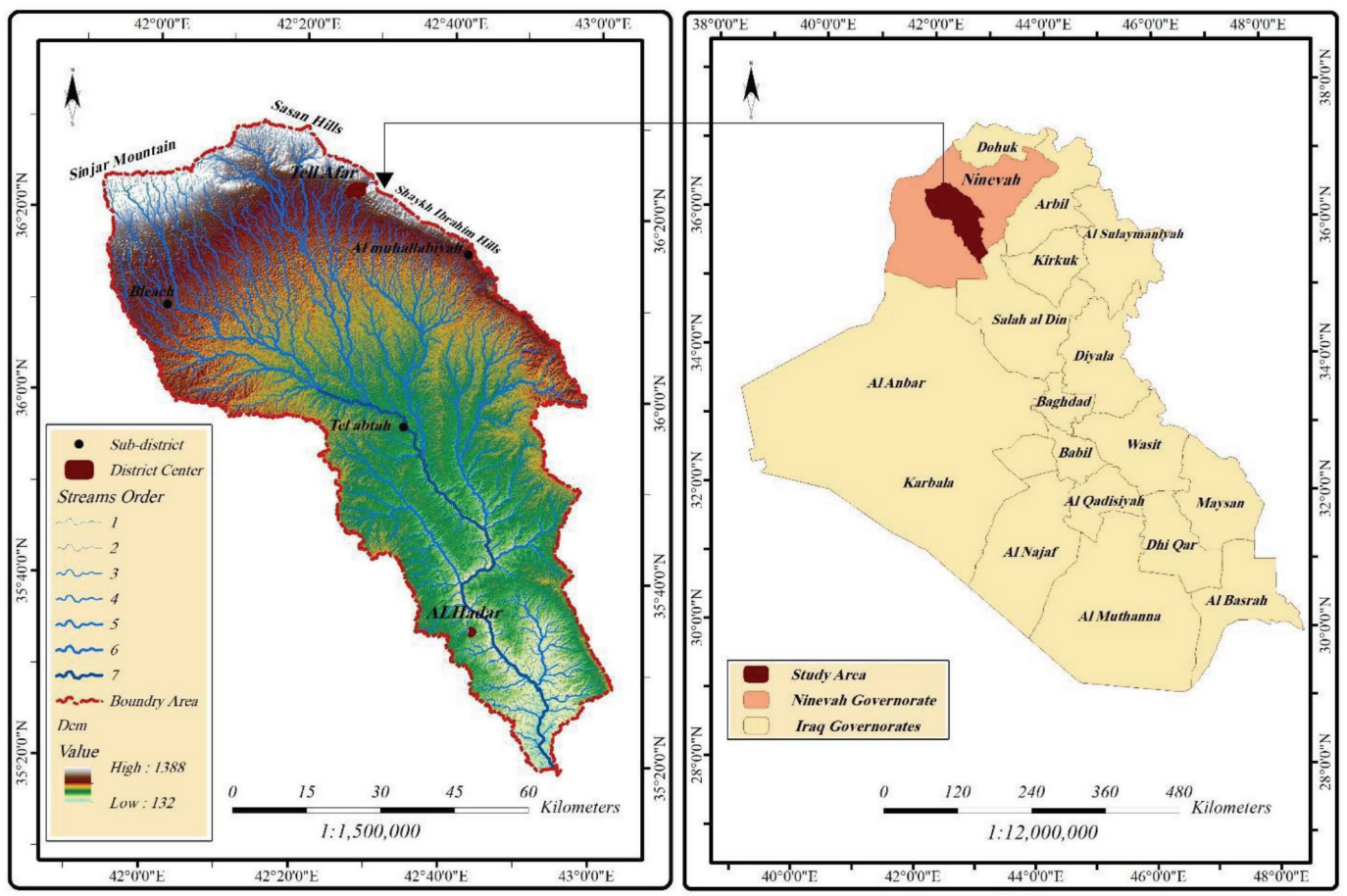

Figure 1: Location of the study area (North AL-Tharthar watershed)

\section{Dataset Collection}

Collecting the spatial dataset is an important step in building a GIS model (Alwan et al.,
2020). The study used maps produced by using various datasets as illustrated in Table 1 . 
Table 1: Dataset sources

\begin{tabular}{|c|c|c|}
\hline$\#$ & Criteria & Source \\
\hline 1 & Slope & \multirow{3}{*}{$\begin{array}{c}\text { Digital Elevation Models (DEM) with } 12.5 \mathrm{~m} \text { resolution obtain from } \\
\text { Alaska Satellite } \\
\text { https://asf.alaska.edu/ }\end{array}$} \\
\hline 2 & Elevation & \\
\hline 3 & Stream orders & \\
\hline 4 & Annual rainfall & $\begin{array}{c}\text { Iraqi Meteorological Organization \& Seismology (coverage } 2000 \text { to } \\
\text { 2014). As measured of } 6 \text { meteorological stations. } \\
\text { http://www.meteoseism.gov.iq/ }\end{array}$ \\
\hline 5 & Soil texture classes & $\begin{array}{c}\text { The Digital Soil Map of the World, FAO/UNESCO, Version 3.6, } \\
\text { January } 2006 \text { and (Buringh, 1960) }\end{array}$ \\
\hline 6 & Land cover/land use & $\begin{array}{c}\text { landsat8, LC08_L1TP_170036_20140321, Earth Explore(USGS), } \\
\text { https://earthexplorer.usgs.gov }\end{array}$ \\
\hline 7 & Runoff depth & $\begin{array}{l}\text { Land cover, Soil map and rainfall data were adopted to produce the } \\
\text { runoff depth }\end{array}$ \\
\hline 8 & $\begin{array}{l}\text { Settlement centers and } \\
\text { roads }\end{array}$ & $\begin{array}{l}\text { Iraqi ministry of Transportation } \\
\text { https://www.motrans.gov.iq/ }\end{array}$ \\
\hline 9 & $\begin{array}{l}\text { Population rural and } \\
\text { agricultural density }\end{array}$ & \multirow{2}{*}{$\begin{array}{c}\text { Directorate of Nineveh Agriculture and Iraqi Central statistical } \\
\text { origination http://cosit.gov.iq/ }\end{array}$} \\
\hline 10 & Livestock water demand & \\
\hline
\end{tabular}

\section{Dataset Processing}

FAO has listed six essential factors for water harvesting site selection (Inamdar et al., 2018). However, this study integrated seven biophysical and four socio-economic criteria. According to literature reviews. socio-economic criteria enhance the process of optimal site selection. Acts as catalyst for sustainable water management, particularly in agriculture areas (Wu et al., 2018). These groups of criteria have not been considered in studies by H. AlArdeeni, 2018; Ibrahim et al., 2019. The criteria of the study area have been processed by using ArcGIS 10.5.

\section{Biophysical Criteria}

\section{Slope}

Slope is the variation between two points within the catchment divided by a horizontal line (Tiwari et al., 2018). Slope is a key parameter in site selection for water harvesting. It has direct impacts on runoff generation, surface water velocity and dams' locations (Ibrahim et al., 2019). Location with slope less than $2 \%$ gives higher storage efficiency with low earthwork needs (Walega \& Salata, 2019). The slope map is shown in Figure 2 (A1) where it has been classified into six categories according to Zuidam et al. (1979).

\section{Elevation}

It's also a criterion that plays a key role in selecting potential water harvesting sites. Elevation has a direct relation with water harvesting because higher elevations are less preferable as they will need many earthworks (Adham et al., 2016). Elevation variations that are susceptible to floods provide very important information for more applicable water harvesting process (Mahmoud \& Gan, 2018). A map is shown in Figure 2 (A2) that classifies elevations into seven classes.

\section{Stream Orders}

The order of streams in the catchment denotes the hierarchical links between stream segments (Adham et al., 2018). It allows the classification of the drainage basin based on their size 
Table 2: Soil hydrological group

\begin{tabular}{cccc}
\hline Soil Group & Potential Runoff & Soil Texture & \% in Study Area \\
\hline A & Low runoff & Sand, Loamy sand and sandy loam & 3.992 \\
B & Moderately low runoff & Silty loam and loam & 51.977 \\
C & Moderately high runoff & Sand clay loam & 44.031 \\
\hline
\end{tabular}

(Ibrahim et al., 2019). Stream order is a critical element in the water harvesting process because higher stream orders have lower permeability and infiltration (Abdulla \& Thomas, 2016). The study area has $7^{\text {th }}$ drainage orders as depicted in Figure 2 (A3), with a total length of 11212.84 $\mathrm{km}$.

\section{Annual Rainfall}

Rainfall is the most influential factor to identify suitable water harvesting. It's a prerequisite for large-scale harvesting infrastructure (Shadmehri et al., 2020). Rainfall is not only the most important parameter in water harvesting mapping, but also is the base and main source of recharge in the catchment (Adham et al., 2018). It has a direct and indirect impact on the majority of other criteria in planning for water harvesting in arid and semi-arid areas. The map in Figure 2 (A4) illustrates the six zones of rainfall.

\section{Soil Texture Classes}

Soil texture classes refer to the percentage of clay, silt and sand in the soil (Rana \& Suryanarayana, 2020). It is one of the key parameters in designing and assessing reliability of water-harvesting processes (Shadmehri et al., 2020). Soil suitability is a critical criterion for water-harvesting site selection ast controls regular hydrological response (Adham et al., 2018). Fine and medium soil textures are typically more preferable for water harvesting because of their higher ability to retain water (Lee et al., 2016). The study area has three soil hydrological groups as depicted in Table 2 and in Figure 2 (A5). The data of soil texture classes taken from the FAO and (Buringh, 1960).

\section{Land Cover/Land Use}

Land cover use is a key criterion for waterharvesting processes. It can affect the hydrological response of streams in a catchment; thus, it will have a sensitive effect on runoff (Ibrahim et al., 2019). Land cover refers to the vegetation cover in an area. It's linked directly to a high proportion of infiltration and low runoff.(Shadmehri et al., 2020). The land use is considered as a key element in selecting and implementing water-harvesting processes (Shanableh et al., 2018). The map of land cover/ land use is in Figure 2 (A6).

\section{Runoff Depth}

Runoff is a significant element in identifying suitable sites for water harvesting (Ibrahim et al., 2019). The runoff estimation the SCS-CN method (NRCS, 2004). The SCS-CN method used widely (Tiwari et al., 2018). Hydrological soil groups (Rana \& Suryanarayana, 2020), land cover / land use and rainfall were used to derive curve numbers to estimate runoff depth in the study area (Maizi et al., 2020). The potential runoff depth of the study area was divided into nine zones and is shown in Figure 2 (A7). The high runoff starts in the north and gradually lowers to the south.

\section{Socio-economic Criteria}

\section{Settlement Centers and Roads}

Proposed sites of water harvesting have to be reasonably accessible for construction, usage and maintenance. However, they should be some distance from main roads. Very close locations to main roads might increase the possibility for 

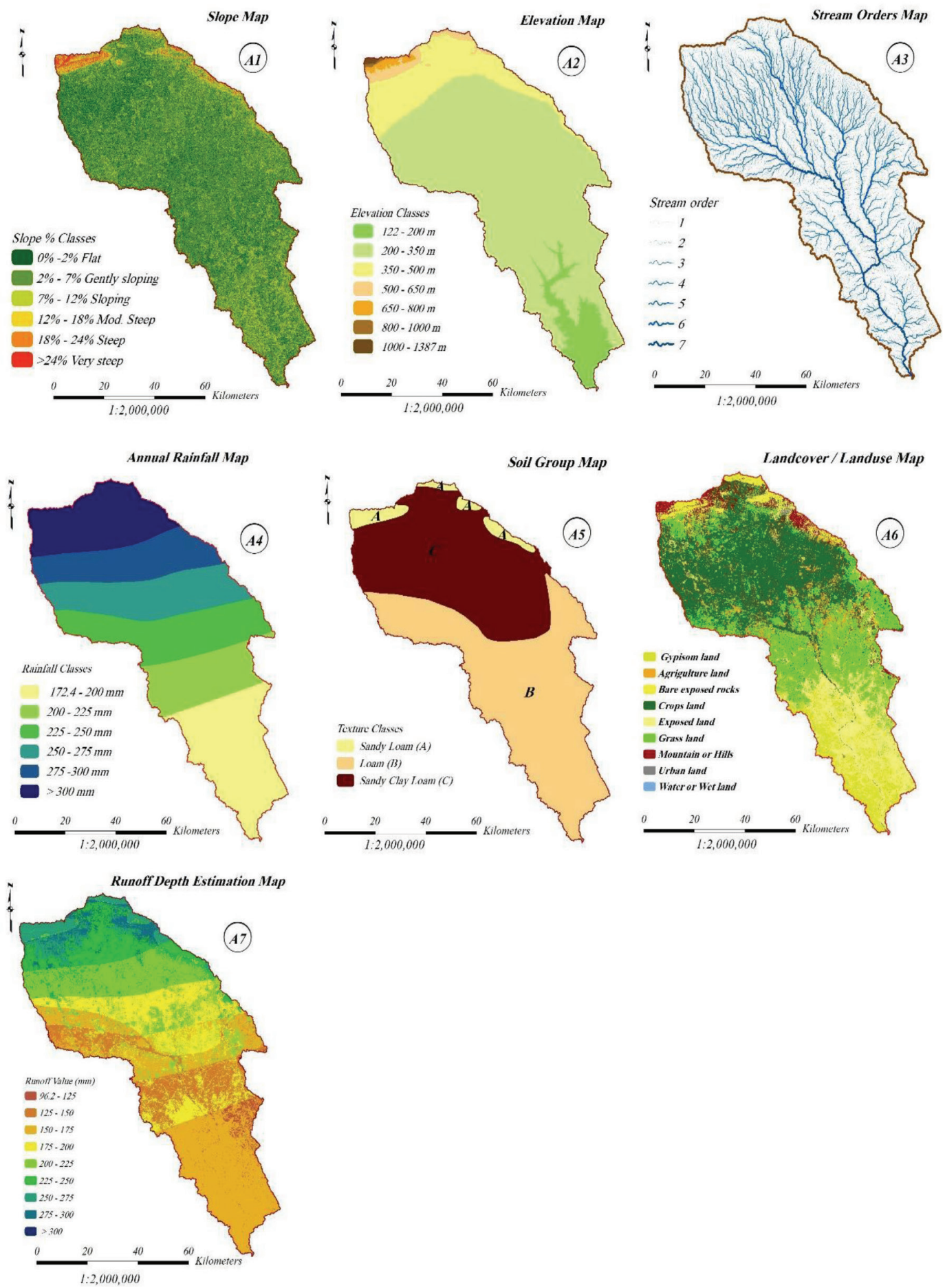

Figure 2: (A1, A2, A3, A4, A5, A6 and A7) of biophysical criteria 
surface water pollution (Wu et al., 2018). The study area has two districts, three sub-districts and 67 villages, which is shown in Figure 3 (B1). The area has a total $55.23 \mathrm{~km}$ and 219.95 $\mathrm{km}$ respectively of main and secondary roads.

\section{Population and Agricultural Density}

The distance from settlements is a key socioeconomic criteria for selecting optimal waterharvesting sites. Proposed sites close to residential areas and agriculture activities are most likely advantageous (Lloyd \& Dennison, 2018). Stored water is a vital potential source for agriculture and population settlement.
Moreover, nearby locations will reduce the distance of pumping and diversion systems, thus it would be preferable for stakeholders as it is cost effective. Distance from agriculture is also an important factor for sustainable waterharvesting and it generally follows the same pattern of distance to population density ( $\mathrm{Wu}$ et al., 2018). Figures 3 (B2) and (B3) illustrate them.

\section{Livestock Water Demand}

The Figure 3 (B4) illustrates the livestock water demand. The water demand refers to the water requirements for many purposes including
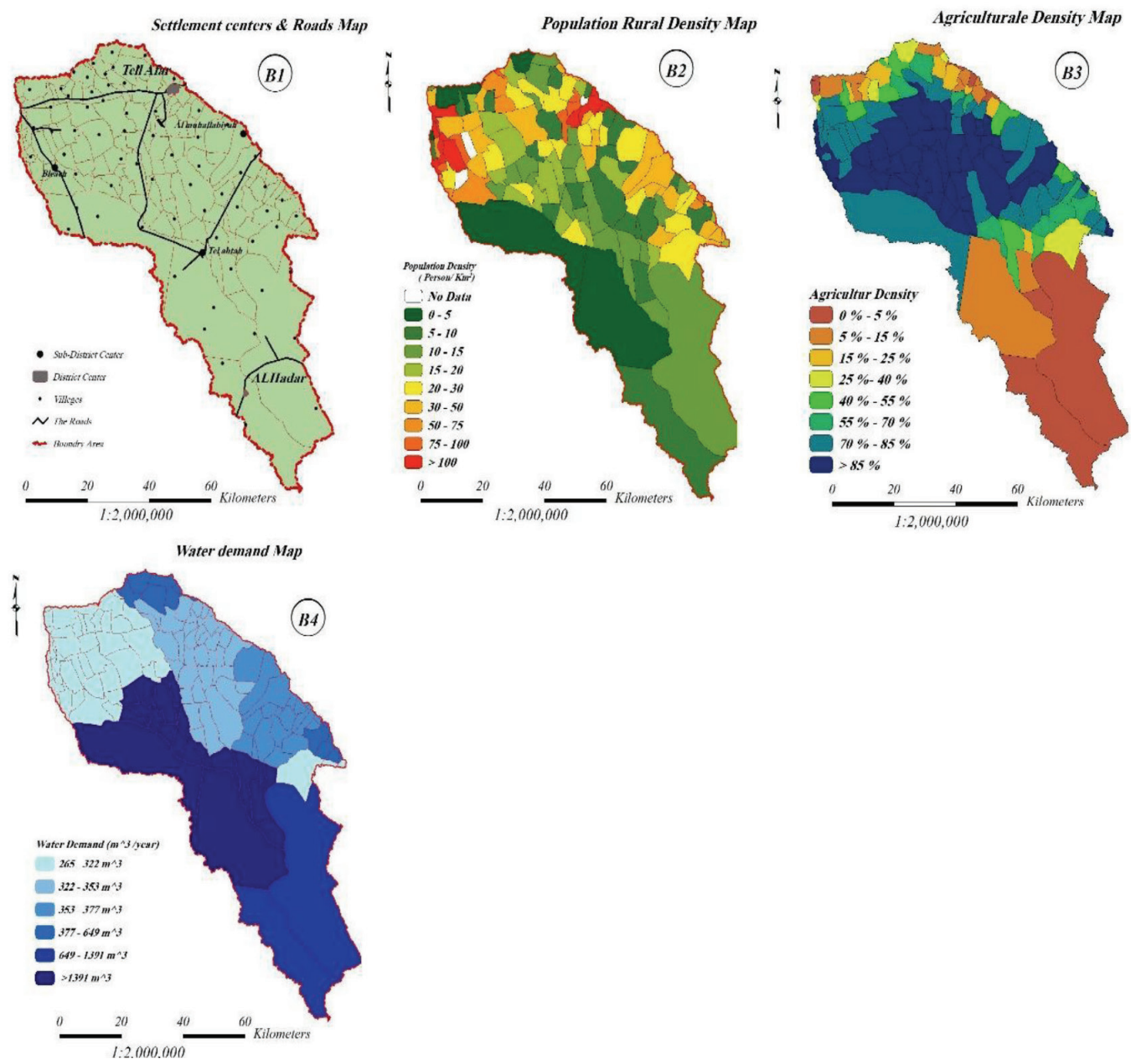

Figure 3: (B1, B2, B3 and B4) socio-economics criteria 
agriculture, domestic use and livestock (Singh et al., 2017). The study area is mainly agricultural, mostly barley and wheat, which consumes about $89 \%$ of its water. Sheep rearing is also a major user. Water demand is estimated based on daily average needs for livestock and crops (AlFuraiji et al., 2016).

\section{Analytic Hierarchy Process (AHP)}

AHP is a statistics tool for multi-criteria decision analysis. It is used to weigh different parameters to prioritize choices among criteria (Saaty, 2008). AHP allows researchers to assign weights of criteria against others (Tupenaite et al., 2017). It iss utilized to weigh criteria separately according to their importance even though they are tangible or intangible (Shanableh et al., 2018). The principle of AHP, according to Ochir et al. (2018), stands on the concept of "Decomposition, comparative judgment and synthesis of priorities". The weights are given from 1-9, where 1 refers to equally important, while 9 means that the parameter has much more importance than others (Saaty, 2008). The AHP method in this study used to weigh and rate input criteria for selecting suitable waterharvesting locations. The weight of certain study criteria was based on experts' opinions, discussion with local authorities and literature review as shown in Table 4 . The Table 3 demonstrates $14 * 14$ of pairwise comparisons. First, set a hierarchy system of variables (Faisal $\&$ Ahmed, 2018). Second, is to derive weights from a pairwise comparison of the importance between each two relevant parameters. Finally, the consistency ratio is calculated according to pair-wise comparison (Ochir et al., 2018). Super Decision (SD) software 20.8 is used to assess weighting accuracy (Faisal \& Ahmed, 2018). The consistency ratio of our AHP matrix is 0.0123 . The criteria weight of the study is acceptable because consistency ratio is less than 0.1 (Alkhatib et al., 2019; Faisal \& Ahmed, 2018; Ochir et al., 2018; Saaty, 2008; Tupenaite et al., 2017)

\section{GIS Model Building}

The suitability model developed using ArcGIS 10.5 creates a water-harvesting map by merging compatibility criteria of both vector and raster databases using a weighted linear combination process. The criteria that were prepared to input into the model includes re-classification of criteria according to the degree of impact and relative importance in Table 3 to obtain criteria weight. Then, after converting the formulas of all parameters from the Vector data to the Raster data weights to each category of these variables as shown in Table 4 were assigned. The model aims to extract the Suitability Degree map by using the approach of average weighted, where it's prepared by multiplying the variable weight obtained through AHP by its rank in Table 4 as in equation 1 . The final output was collected to obtain the pixel validity of the map in percentage by using the Algebra expression (Raster Calculator). The highest pixel values are isolated, which represents the highest degree of validity through using the same tool. Figure 4 expresses model steps.

D. $S=\sum \quad$ WiXiD. $S=\frac{(X x * W x) * 100}{900} \quad \ldots \ldots .1$ 


\begin{tabular}{|c|c|c|c|c|c|c|c|c|c|c|c|c|c|c|c|}
\hline & 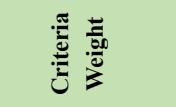 & 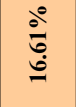 & 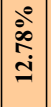 & $\begin{array}{l}\stackrel{\circ}{\circ} \\
\stackrel{0}{0} \\
\stackrel{\theta}{=}\end{array}$ & $\stackrel{\stackrel{\circ}{0}}{\stackrel{0}{\varrho}}$ & $\begin{array}{l}\circ \\
\dot{\Xi} \\
\grave{\Xi}\end{array}$ & 产 & 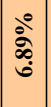 & $\stackrel{\stackrel{9}{+}}{\stackrel{+}{+}}$ & 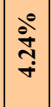 & 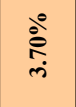 & 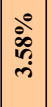 & $\begin{array}{c}\stackrel{0}{0} \\
\stackrel{\infty}{i} \\
i\end{array}$ & 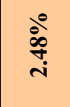 & ڤั: \\
\hline \pm & 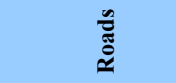 & $r$ & 0 & 0 & in & in & in & $\nabla$ & $m$ & $m$ & $N$ & $N$ & $N$ & $\sim$ & \\
\hline 9 & 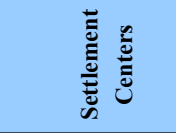 & 0 & $\sigma$ & $\nabla$ & $\sigma$ & $\sigma$ & $\sigma$ & $\infty$ & N & $N$ & $N$ & $\sim$ & - & & 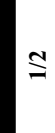 \\
\hline$\simeq$ & 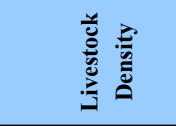 & 0 & in & $\nabla$ & $\nabla$ & $m$ & $m$ & $m$ & $N$ & N & - & - & & - & 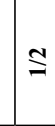 \\
\hline$=$ & 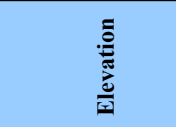 & in & $\nabla$ & $\nabla$ & $m$ & m & $m$ & $\boldsymbol{N}$ & - & - & - & & - & 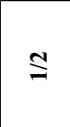 & 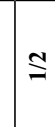 \\
\hline$\varrho$ & 焉 & + & m & m & $m$ & $m$ & $N$ & $N$ & - & - & & -1 & - & $S$ & 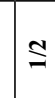 \\
\hline$a$ & 气 $\frac{3}{0}$ & in & $\sigma$ & $m$ & $m$ & $m$ & $\infty$ & $N$ & - & & - & - & 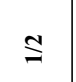 & $S$ & $\stackrel{m}{=}$ \\
\hline$\infty$ & 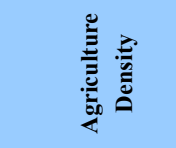 & in & $\sigma$ & $m$ & $m$ & $m$ & $m$ & $\sim$ & & - & - & -1 & $\mathfrak{I}$ & $S$ & $\stackrel{m}{=}$ \\
\hline$r$ & 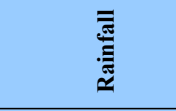 & $\nabla$ & $\infty$ & $\sim$ & N & N & N & & $S$ & $\mathbf{S}$ & $\mathbf{S}$ & $\mathbf{I}$ & $\stackrel{m}{=}$ & $\stackrel{m}{=}$ & \pm \\
\hline 0 & $\overline{\bar{B}} \overline{\bar{z}}$ & N & - & - & - & - & 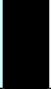 & 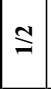 & 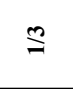 & $\stackrel{m}{2}$ & $\mathbf{S}$ & $\stackrel{m}{=}$ & 9 & 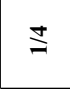 & $\stackrel{m}{=}$ \\
\hline in & $\frac{\check{\partial}}{\text { के }}$ & N & - & - & - & & - & 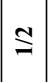 & $\stackrel{m}{=}$ & $\stackrel{m}{2}$ & $\stackrel{m}{2}$ & 9 & $\stackrel{m}{=}$ & $\Xi$ & $\stackrel{\text { in }}{=}$ \\
\hline+ & 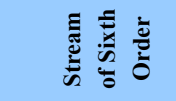 & $N$ & - & - & & - & - & $\stackrel{\mathbf{S}}{\mathbf{S}}$ & 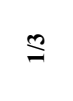 & $\stackrel{m}{2}$ & 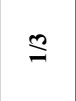 & $\stackrel{m}{=}$ & \pm & \pm & $\stackrel{\stackrel{2}{=}}{=}$ \\
\hline $\mathrm{m}$ & 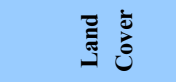 & n & $N$ & & - & - & - & 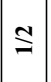 & $\stackrel{m}{=}$ & $\stackrel{m}{2}$ & $\stackrel{m}{2}$ & \pm & \pm & $\Xi$ & $\stackrel{\circ}{\varrho}$ \\
\hline$N$ & $\stackrel{\equiv}{\approx}$ & - & & 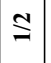 & - & - & - & 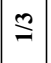 & \pm & $\Xi$ & 3 & \pm & $\stackrel{n}{=}$ & \pm & $\stackrel{\circ}{=}$ \\
\hline- & 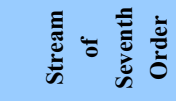 & & - & 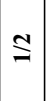 & $S$ & 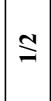 & 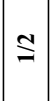 & $\Xi$ & $\stackrel{1}{=}$ & $\stackrel{2}{2}$ & $\Xi$ & $\stackrel{\infty}{=}$ & $\stackrel{0}{=}$ & $\stackrel{\varrho}{=}$ & 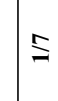 \\
\hline \multirow{3}{*}{\multicolumn{2}{|c|}{ 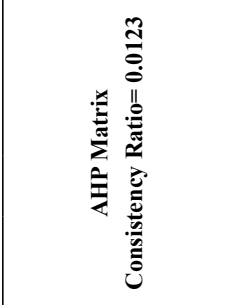 }} & 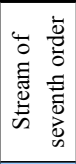 & 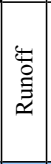 & 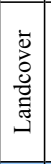 & 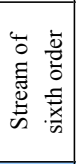 & $\frac{0}{\frac{0}{b}}$ & 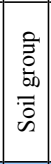 & 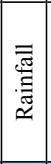 & 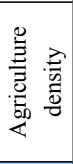 & 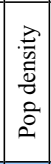 & 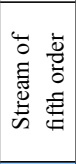 & 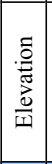 & 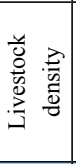 & 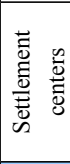 & 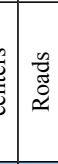 \\
\hline & & - & $N$ & $m$ & + & in & 0 & $r$ & $\infty$ & $a$ & $\varrho$ & $=$ & $\simeq$ & 9 & \pm \\
\hline & & \multicolumn{14}{|c|}{$\begin{array}{l}\ddot{\ddot{E}} \\
\ddot{\Xi}\end{array}$} \\
\hline
\end{tabular}




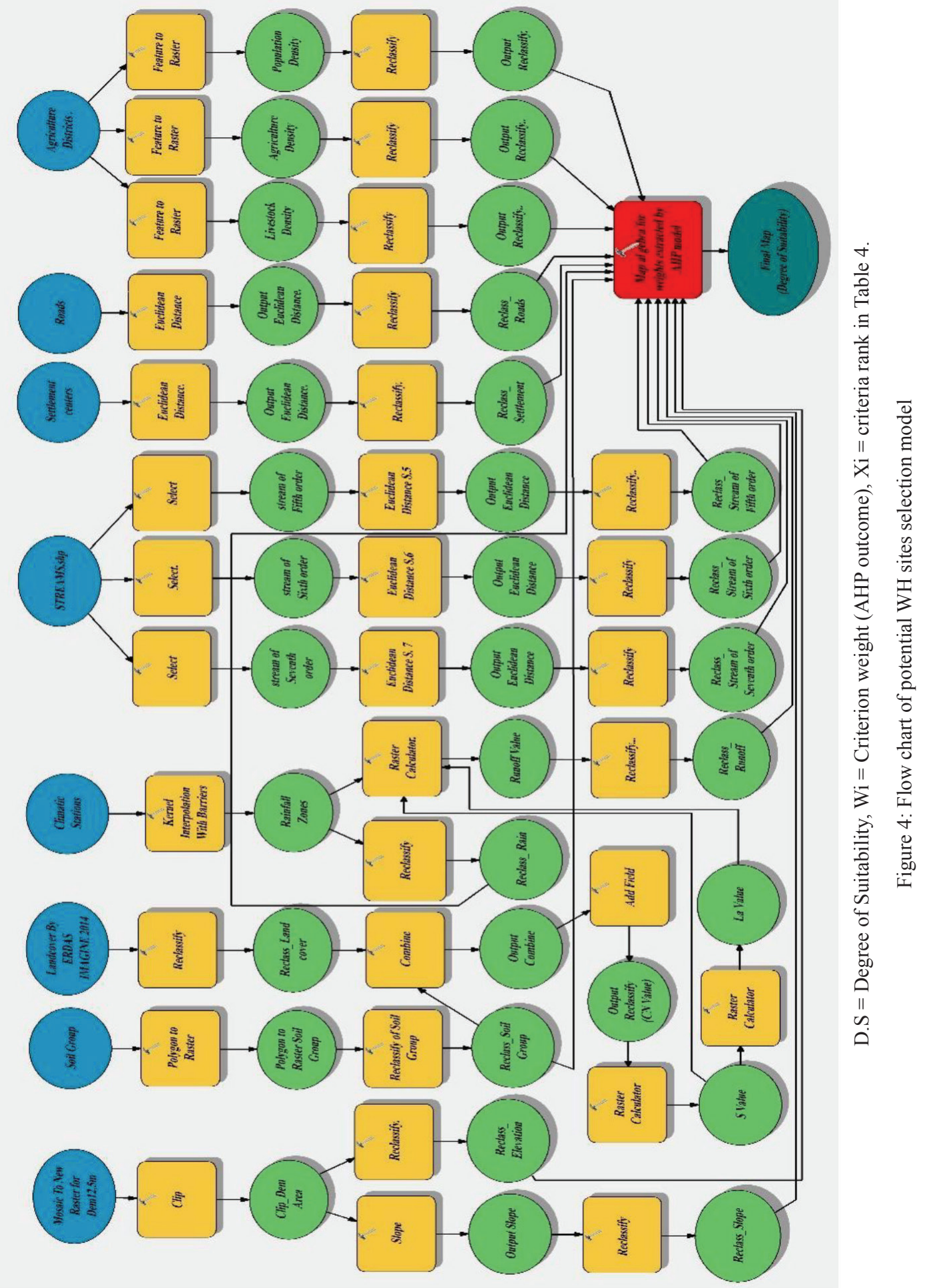


Table 4: Biophysical and socio-economic criteria, rank, sub-class and AHP weight

\begin{tabular}{|c|c|c|c|c|}
\hline \multicolumn{5}{|c|}{ Biophysical Criteria } \\
\hline No. & Variable & Classes & Rank & AHP \\
\hline \multirow{4}{*}{1} & \multirow{4}{*}{ Stream of seventh order } & $0-1000 \mathrm{~m}$ & 9 & \multirow{4}{*}{$16.61 \%$} \\
\hline & & $1000-2000 \mathrm{~m}$ & 6 & \\
\hline & & $2000-3000 \mathrm{~m}$ & 3 & \\
\hline & & $>3000 \mathrm{~m}$ & 1 & \\
\hline \multirow{4}{*}{2} & \multirow{4}{*}{ Stream of sixth order } & $0-1000 \mathrm{~m}$ & 9 & \multirow{4}{*}{$10.38 \%$} \\
\hline & & $1000-2000 \mathrm{~m}$ & 6 & \\
\hline & & $2000-3000 \mathrm{~m}$ & 3 & \\
\hline & & $>3000 \mathrm{~m}$ & 1 & \\
\hline \multirow{4}{*}{3} & \multirow{4}{*}{ Stream of fifth order } & $0-1000 \mathrm{~m}$ & 9 & \multirow{4}{*}{$3.70 \%$} \\
\hline & & $1000-2000 \mathrm{~m}$ & 6 & \\
\hline & & $2000-3000 \mathrm{~m}$ & 3 & \\
\hline & & $>3000 \mathrm{~m}$ & 1 & \\
\hline \multirow{9}{*}{4} & \multirow{9}{*}{ Runoff } & $96.2-125(\mathrm{~mm})$ & 1 & \multirow{9}{*}{$12.78 \%$} \\
\hline & & $125-150(\mathrm{~mm})$ & 2 & \\
\hline & & $150-175(\mathrm{~mm})$ & 3 & \\
\hline & & $175-200(\mathrm{~mm})$ & 4 & \\
\hline & & $200-225(\mathrm{~mm})$ & 5 & \\
\hline & & $225-250(\mathrm{~mm})$ & 6 & \\
\hline & & $250-275(\mathrm{~mm})$ & 7 & \\
\hline & & $275-300(\mathrm{~mm})$ & 8 & \\
\hline & & $>300(\mathrm{~mm})$ & 9 & \\
\hline \multirow{9}{*}{5} & \multirow{9}{*}{ Land cover/land use } & $\begin{array}{c}\text { Urban \& settlement Rural } \\
\text { land }\end{array}$ & 0 & \multirow{9}{*}{$10.86 \%$} \\
\hline & & Gypsum land & 2 & \\
\hline & & Mountain or hills & 3 & \\
\hline & & Bare exposed rocks & 3 & \\
\hline & & Exposed land & 6 & \\
\hline & & Grassland & 8 & \\
\hline & & Agriculture land & 8 & \\
\hline & & Water or wet land & 8 & \\
\hline & & Crops land & 9 & \\
\hline \multirow{3}{*}{6} & \multirow{3}{*}{ Soil group } & A & 3 & \multirow{3}{*}{$9.74 \%$} \\
\hline & & B & 6 & \\
\hline & & $\mathrm{C}$ & 9 & \\
\hline \multirow{6}{*}{7} & \multirow{6}{*}{ Rainfall } & $172.4-200(\mathrm{~mm})$ & 2 & \multirow{6}{*}{$6.89 \%$} \\
\hline & & $200-225(\mathrm{~mm})$ & 3 & \\
\hline & & $225-250(\mathrm{~mm})$ & 5 & \\
\hline & & $250-275(\mathrm{~mm})$ & 7 & \\
\hline & & $275-300(\mathrm{~mm})$ & 8 & \\
\hline & & $>300(\mathrm{~mm})$ & 9 & \\
\hline
\end{tabular}

Journal of Sustainability Science and Management Volume 16 Number 7, October 2021: 218-236 


\section{Biophysical Criteria}

\begin{tabular}{|c|c|c|c|c|}
\hline No. & Variable & Classes & Rank & AHP \\
\hline \multirow{6}{*}{8} & \multirow{6}{*}{ Slope } & $0 \%-2 \%$ Flat & 7 & \multirow{6}{*}{$10.06 \%$} \\
\hline & & $2 \%-7 \%$ Gently sloping & 9 & \\
\hline & & $7 \%-12 \%$ Sloping & 7 & \\
\hline & & $12 \%-18 \%$ Mod. steep & 5 & \\
\hline & & $18 \%-24 \%$ Steep & 3 & \\
\hline & & $>24 \%$ Very steep & 1 & \\
\hline \multirow{7}{*}{9} & \multirow{7}{*}{ Elevation } & $122-200 \mathrm{~m}$ & 9 & \multirow{7}{*}{$3.58 \%$} \\
\hline & & $200-350 \mathrm{~m}$ & 8 & \\
\hline & & $350-500 \mathrm{~m}$ & 6 & \\
\hline & & $500-650 \mathrm{~m}$ & 4 & \\
\hline & & $650-800 \mathrm{~m}$ & 2 & \\
\hline & & $800-1000 \mathrm{~m}$ & 1 & \\
\hline & & $1000-1387 \mathrm{~m}$ & 0 & \\
\hline
\end{tabular}

Socio-economic Criteria

\begin{tabular}{|c|c|c|c|c|}
\hline No. & Variable & Classes & Rank & AHP \\
\hline 1 & Settlement centers & $\begin{array}{c}0-1000 \mathrm{~m} \\
1000-2000 \mathrm{~m} \\
2000-3000 \mathrm{~m} \\
3000-4000 \mathrm{~m} \\
>4000 \mathrm{~m}\end{array}$ & $\begin{array}{l}0 \\
9 \\
7 \\
5 \\
3\end{array}$ & $2.48 \%$ \\
\hline 2 & Agriculture density & $\begin{array}{c}0-17.5 \\
17.5-35 \\
35-52.5 \\
52.5-70 \\
>70\end{array}$ & $\begin{array}{l}2 \\
4 \\
6 \\
8 \\
9\end{array}$ & $4.24 \%$ \\
\hline 3 & Population density & $\begin{array}{c}0-5 \\
5-10 \\
10-15 \\
15-20 \\
20-30 \\
30-40 \\
>40\end{array}$ & $\begin{array}{l}2 \\
2 \\
4 \\
4 \\
6 \\
8 \\
9\end{array}$ & $4.24 \%$ \\
\hline 4 & $\begin{array}{c}\text { Livestock water } \\
\left.\text { demand ( } \mathrm{mm}^{3} / \text { year }\right)\end{array}$ & $\begin{array}{c}264-500 \\
500-750 \\
750-1000 \\
>1000\end{array}$ & $\begin{array}{l}3 \\
5 \\
7 \\
9\end{array}$ & $2.83 \%$ \\
\hline 5 & Roads & $\begin{array}{c}0-150 \mathrm{~m} \\
150-1000 \mathrm{~m} \\
1000-2000 \mathrm{~m} \\
>2000 \mathrm{~m}\end{array}$ & $\begin{array}{l}0 \\
9 \\
7 \\
5\end{array}$ & $1.59 \%$ \\
\hline
\end{tabular}




\section{Results and Discussion}

\section{Potential Water-Harvesting Sites}

The map in Figure 5 shows the results of the suitability degree for water harvesting and location of potential dams. It was developed by integrating multi-criteria evaluation by GIS based on an AHP statistical method, taking into account 14 layers, in order to yield the final map of optimal water harvesting suitability. Five comparable classes are used to indicate the degree of suitability for potential waterharvesting sites: very high suitability, high suitability, medium suitability, low suitability and very low suitability. Figure 5 indicates that the north and middle of the study area are much more suitable for water harvesting compared to the south. The outcomes show that medium suitability has the largest percentage at $37.77 \%$ $\left(2315.72 \mathrm{~km}^{2}\right)$ followed by low suitability at $29.10 \%\left(1784 \mathrm{~km}^{2}\right)$ and then high suitability at $24.895 \%(1525.9 \mathrm{~km} 2)$. However, very low suitability and very high suitability covers $6.881 \%(421.80 \mathrm{~km} 2)$ and $1.339 \%(82.06 \mathrm{~km} 2)$ respectively. As illustrated in Figure 6, around $63 \%$ of the study area is suitable for water harvesting. In addition, the three dams were located in high suitability areas. Table 5 shows the coordinates for them.

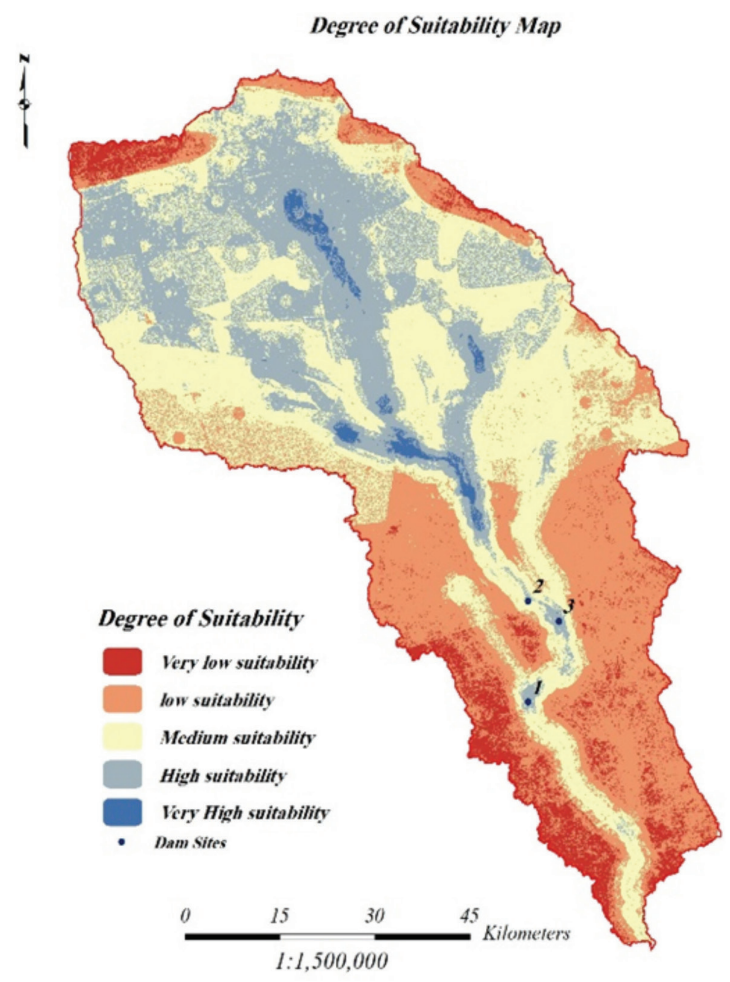

Figure 5: Degree of suitability and potential suitable sites for water harvesting

Table 5: Storage capacity and coordinates of proposed dams

\begin{tabular}{cccc}
\hline Dam & Storage Capacity $\left(\mathbf{m}^{3}\right)$ & Latitude & Longitude \\
\hline 1 & $37,359,680.5$ & $35^{\circ} 39^{\prime} 5.8196^{\prime \prime} \mathrm{N}$ & $42^{\circ} 42^{\prime} 26.8565^{\prime \prime} \mathrm{E}$ \\
2 & $76,273,409.9$ & $35^{\circ} 47^{\prime} 20.5545^{\prime \prime} \mathrm{N}$ & $42^{\circ} 42^{\prime} 13.8538^{\prime \prime} \mathrm{E}$ \\
3 & $9,690,685.6$ & $35^{\circ} 45^{\prime} 45.4550^{\prime} \mathrm{N}$ & $42^{\circ} 45^{\prime} 31.4739^{\prime} \mathrm{E}$ \\
\hline
\end{tabular}




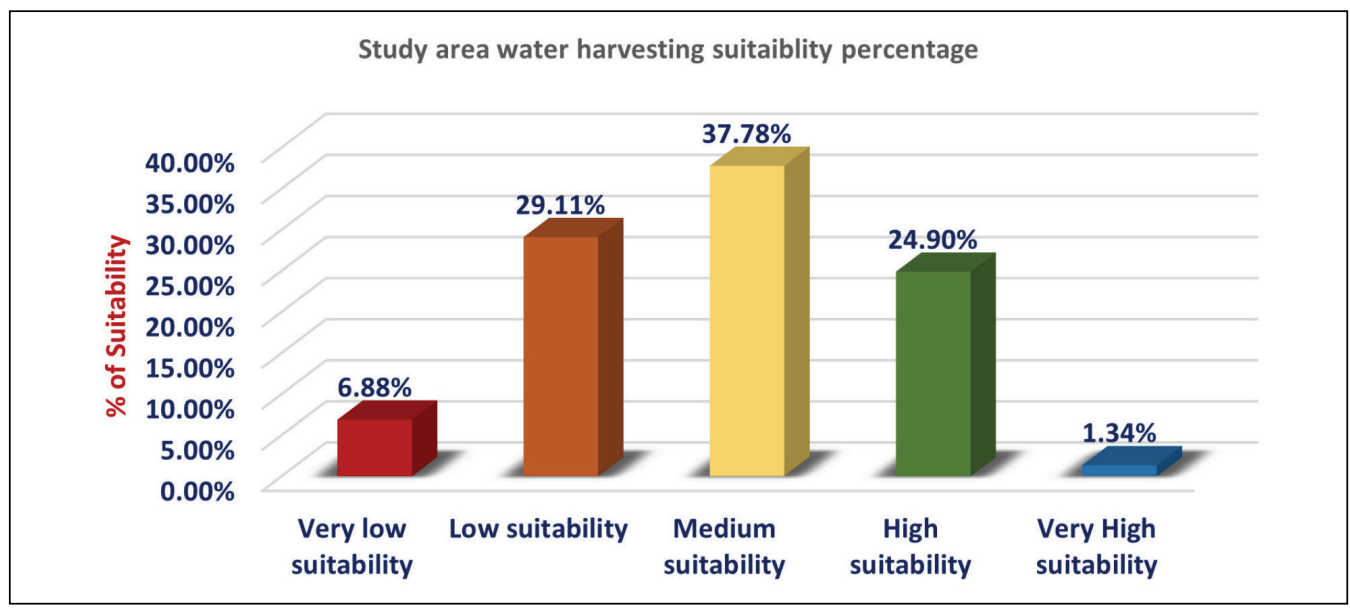

Figure 6: Percentage of water harvesting suitability in the research area

\section{Proposed Sites for Dams}

Dams are the most common and appropriate structure for water harvesting (Adham et al., 2018). The Triangulated Irregular Network (TIN), drainage layer and contour lines functions of the ArcScene program are used to get a cross-section profile of the proposed dam sites in the study area. The TIN and polygon volume tools are used to calculate volume and height of dams with contour interval $2 \mathrm{~m}$. The storage capacity and profile of the three potential dams are shown in Figure 7.

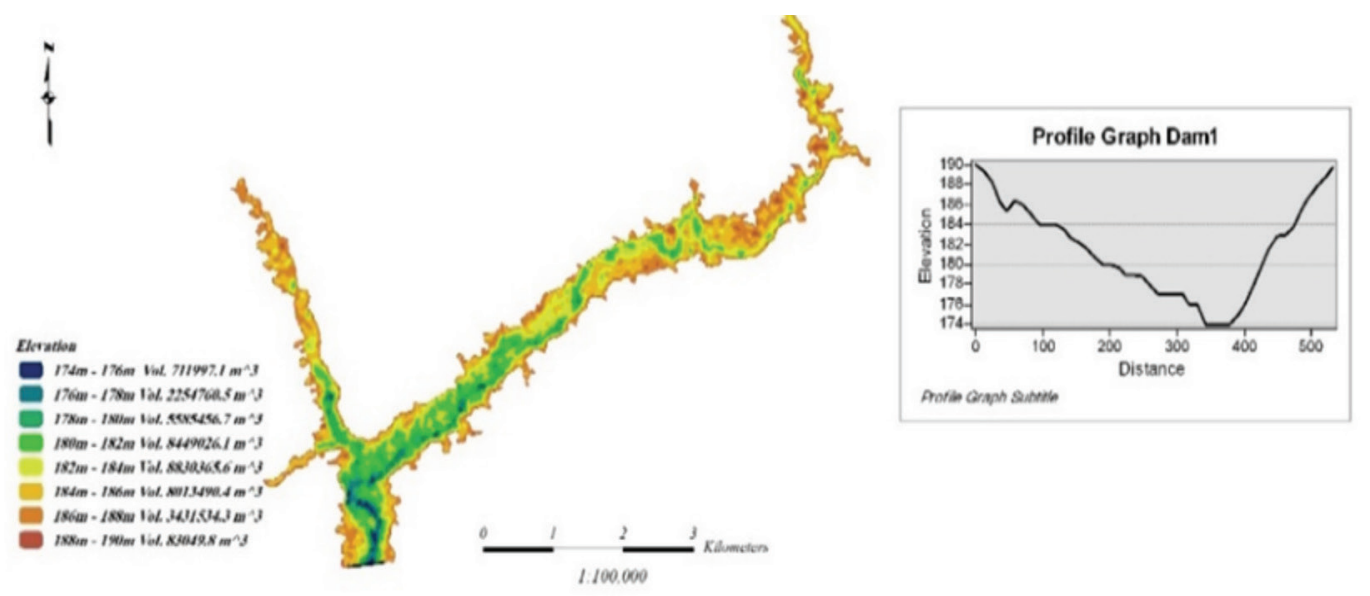



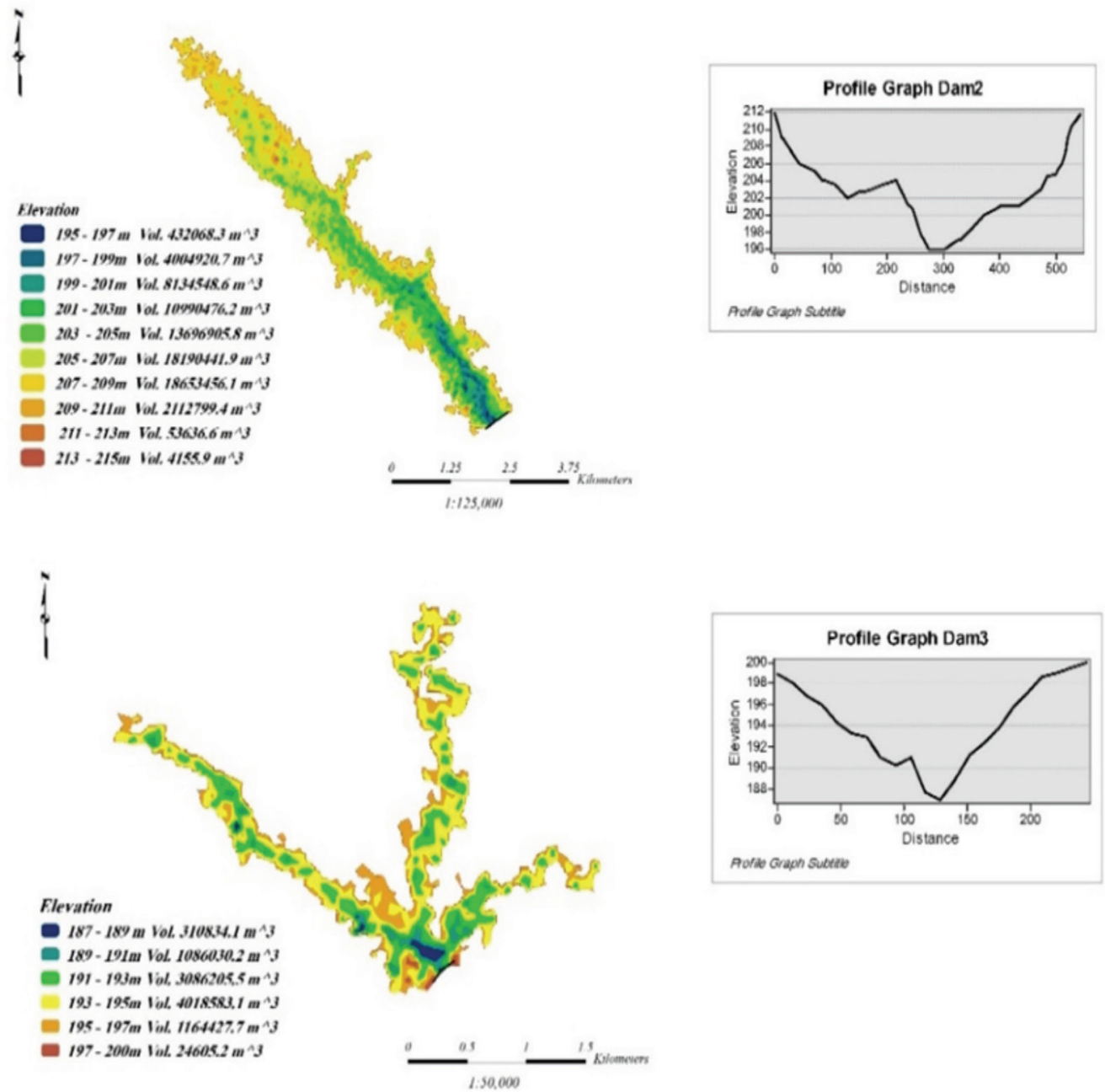

Figure 7: Proposed dams' details, elevation, cross section and storage capacity in the study area

The results of the model and AHP analysis indicate that the study area is suitable for building water harvesting structures. From the central to northern region, a medium degree of suitability is found. The suggested sites have gentle slopes, which are crucial elements in water-harvesting structures as they enhance collection of runoffs. Ibrahim et al. (2019) suggested that slopes steeper than $7 \%$ are unsuitable due to irregular and rough runoff flow. They also require more earthworks. The potential sites are in zones receiving enough annual rainfall to trigger reasonable amounts of runoff. Stream order is a key element in the selection of harvesting sites. It reflects the permeability and infiltration of water. However, higher stream order is directly proportional to the high runoff supply of potential storage sites. The three dams are located on $7^{\text {th }}$ order streams, so they have continuous water flow.

All proposed sites are very close to intense agriculture activities, and will serve agricultural demand for water, including livestock. The sites are near, but not too close to main and secondary roads, as the distance $(0-150 \mathrm{~m})$ is restricted $(\mathrm{Wu}$ et al., 2018). They are also near the villages, so that not many earthworks are needed. These structures in inhabited croplands are more 
practical than relocating them to potential harvesting sites. The results of this study agree with previous studies on water harvesting site selection (Adham et al., 2018; Alwan et al., 2020; H. Al-Ardeeni, 2018; Ibrahim et al., 2019; Salman et al., 2017; Walega \& Salata, 2019). These locations for water harvesting can fulfil the water demand for livestock, agriculture as well as human populations (Krois \& Schulte, 2014). Water harvesting could raise agriculture production and can be an alternative source of water (Perez-Uresti et al., 2019). The proposed locations are in an area facing high risk of drought.

This research has valuable outcomes as it suggests a sustainable solution for water shortage in arid regions. However, it emphasizes that the model does not take into consideration the economic feasibility of implementing a water harvesting system and the quality of stored water. Therefore, future research on such aspects should be done.

\section{Conclusion}

Water harvesting is a potential technique to effectively cope with water scarcity. The study is conducted on a large watershed in Iraq that is facing water scarcity. The study was based on the suitability model derived from ArcGIS 10.5, GIS-based multi criteria and AHP tool to determine the potential site for water harvesting. This study also tries to incorporate biophysical and socio-economic criteria in the selection for suitable water harvesting sites. The study indicates that GIS-based multi-criteria can produce an integrated model, which is very effective in achieving the objectives of the study. The results concluded that the northern and central sections of the study area have higher degree of suitability for water harvesting. These areas have higher elevation, rainfall, runoff rate and complex drainage networks compared to the southern part. The three proposed sites for dams are in a high suitability area with reasonable storage capacity. For further validation, field work investigation will provide more insight into socio-economics parameters.

\section{Acknowledgements}

The authors are very grateful to the College of Environmental Sciences and Technology University of Mosul for their facilities, which helped to improve the quality of this work.

\section{References}

Abdulla, U. N., T., \& Thomas, R. (2016). Identification of suitable sites for water harvesting structures in Kecheri River Basin. Procedia Technology Procedia Technology, 24, 7-14.

Adham, A., Abed, R., Abdeladhim, M. A., Wesseling, J. G., Riksen, M., Fleskens, L., \& Karim, U. (2018). A GIS-based approach for identifying potential sites for harvesting rainwater in the Western Desert of Iraq. Int. Soil Water Conserv. Res. International Soil and Water Conservation Research, 6(4), 297-304.

Adham, A., Riksen, M., Ouessar, M., \& Ritsema, C. (2016). A methodology to assess and evaluate Rainwater Harvesting Techniques in (Semi-) Arid Regions. Water Water, 8(5), 198.

Al-Furaiji, M. H. O., Waisi, B. I. H., Al-Furaiji, M. H. O., Karim, U. F. A., Augustijn, D. C. M., \& Hulscher, S. J. M. H. (2016). Evaluation of water demand and supply in the south of Iraq. J. Water Reuse Desalin. Journal of Water Reuse and Desalination, 6(1), 214-226.

Al-Jarjees, S. D. K. k. A.-A. (2020). The usage of GIS for the devastated urban centers management and preservation of monuments/study case: Nabi-Jarjis District in Mosul City in Iraq. The Iraqi Geological Journal, 53(1B), 57-69.

Al-Ozeer, A. Z., Mohammed A. Abdaki, Ahmed R. Al-Iraqi, Sufyan H. Al-Samman, \& AlHammadi, N. A. (2020). Estimation of mean areal rainfall and missing data by using GIS in Nineveh, northern Iraq. Iraqi Geological Journal, 53(1E), 93-103. 
Alkhatib, J., Engelhardt, I., Ribbe, L., \& Sauter, M. (2019). An integrated approach for choosing suitable pumping strategies for a semi-arid region in Jordan using a groundwater model coupled with analytical hierarchy techniques. Hydrogeol $J$ Hydrogeology Journal.

Alwan, I. A., Aziz, N. A., \& Hamoodi, M. N. (2020). Potential water harvesting sites identification using Spatial Multi-Criteria Evaluation in Maysan Province, Iraq. ISPRS International Journal of Geo-Information, 9(4). doi:10.3390/ijgi9040235

Buringh, P. (1960). Soils and soil conditions in Iraq. Baghdad: Ministry of agriculture.

Campisano, A., D’Amico, G., \& Modica, C. (2017). Water saving and cost analysis of large-scale implementation of domestic rain water harvesting in minor Mediterranean islands. Water Water (Switzerland), 9(12).

Faisal, R. M., \& Ahmed, M. F. A. D. (2018). GIS and AHP based modeling for landfill site selection (case study: West side of Mosul city). Sci. Rev. Eng. Environ. Sci. Scientific Review Engineering and Environmental Sciences, 27(4), 425-437.

H. Al-Ardeeni, M. A. (2018). Selecting potential water harvest sites using GIS and remote sensing in Al-Tharthar Valley, West Nineveh, Iraq. Tikrit Journal of Pure Science, 20(2), 142-150.

Haile, G., \& Suryabhagavan, K. V. (2019). GIS-based approach for identification of potential rainwater harvesting sites in Arsi Zone, Central Ethiopia. Modeling Earth Systems and Environment, 5(1), 353-367. doi:10.1007/s40808-018-0537-7

Hari, D., Vikas, K., Srinivas, N., Vikas, G., Ramamohan Reddy, K., International Conference on Recent Advances in Materials, M., \& Civil Engineering, I. (2018). Assessment of rainwater harvesting potential using GIS. IOP Conf. Ser. Mater. Sci. Eng. IOP Conference Series: Materials Science and Engineering, 330(1).
Ibrahim, G. R. F., Rasul, A., Ali Hamid, A., Ali, Z. F., \& Dewana, A. A. (2019). Suitable site selection for rainwater harvesting and storage case study using Dohuk Governorate. Water, 11(4). doi:10.3390/ w11040864

Inamdar, P. M., Sharma, A. K., Cook, S., \& Perera, B. J. C. (2018). Evaluation of stormwater harvesting sites using multi criteria decision methodology. HYDROL Journal of Hydrology, 562, 181-192.

Krois, J., \& Schulte, A. (2014). GIS-based multicriteria evaluation to identify potential sites for soil and water conservation techniques in the Ronquillo watershed, northern Peru. Appl. Geogr. Applied Geography, 51, 131142.

Lee, K. E., Mokhtar, M., Mohd, M., Abdul, A., \& Badusah, J. (2016). Rainwater harvesting as an alternative water resource in Malaysia: Potential, policies and development. Journal of Cleaner Production, 126, 218222.

Lloyd, B. J., \& Dennison, P. E. (2018). Evaluating the response of conventional and water harvesting farms to environmental variables using remote sensing. Agric. Ecosyst. Environ. Agriculture, Ecosystems and Environment, 262, 11-17.

Mahmoud, S. H., \& Gan, T. Y. (2018). Multicriteria approach to develop flood susceptibility maps in arid regions of Middle East. Journal of Cleaner Production Journal of Cleaner Production, 196, 216229.

Maizi, D., Boufekane, A., Ait Ouali, K., \& Aoudia, M. (2020). Identification of potential area of recharge using geospatial and multi-criteria decision analysis in the Macta watershed (Western Algeria). Arabian Journal of Geosciences, 13(3). doi:10.1007/s12517-020-5076-7

NRCS, N. R. C. S. (2004). Estimation of direct runoff from storm rainfall. In Part 630 Hydrology National Engineering 
Handbook. Washington, DC: U.S. Salman, S. A., Shahid, S., Ismail, T., Chung, Department of Agriculture. E.-S., \& Al-Abadi, A. M. J. A. R. (2017). Long-term trends in daily temperature extremes in Iraq. 198, 97-107.

Ochir, A., Tsetsgee, S., Boldbaatar, D., Zorigt, M., \& van Genderen, J. L. (2018). Site selection for water harvesting ponds using spatial multi-criteria analysis in a region with fluctuating climate. Geocarto Int. Geocarto International, 33(7), 699-712.

Parkinson, S. C., Makowski, M., Krey, V., Sedraoui, K., Almasoud, A. H., \& Djilali, N. (2018). A multi-criteria model analysis framework for assessing integrated waterenergy system transformation pathways. Applied energy., 210, 477-486.

Perez-Uresti, S. I., Jimenez-Gutierrez, A., \& Ponce-Ortega, J. M. (2019). A multiobjective optimization approach for sustainable water management for places with over-exploited water resources. Comput. Chem. Eng. Computers and Chemical Engineering, 158-173.

Rahi, K. A., \& Halihan, T. (2018). Salinity evolution of the Tigris River. Reg Environ Change Regional Environmental Change, 18(7), 2117-2127.

Rana, V. K., \& Suryanarayana, T. M. V. (2020). GIS-based multi criteria decision making method to identify potential runoff storage zones within watershed. Annals of GIS, 1-20. doi:10.1080/19475683.2020.1733083

Saaty, T. L. (2008). Decision making with the analytic hierarchy process. International Journal of Services Sciences, 1(1), 83-98.

Sagar, K., Simran Chauhan, Hitesh Raavi, Divya Gupta,, \& Chauhan, V. (2017). Site selection of water conservation measures by using RS and GIS: A review. Advances in Computational Sciences and Technology, 10(0973-6107), 805-813.

Saleh, S., Abdulrahman, O. R., \& Mehdi Salih, A. (2018). Innovated method to estimate the water income in the section of Tharthar Valley near the Site of Hatra Proposed Dam. Tikrit Journal of Pure Science, 22(6), 88-102.

Sarzaeim, P., Bozorg-Haddad, O., FallahMehdipour, E., \& Loáiciga, H. A. (2017). Environmental water demand assessment under climate change conditions. Environ Monit Assess Environmental Monitoring and Assessment, 189(7).

Selamat, S. N., Maulud, K. N. A., Mohd, F. A., Ab Rahman, A. A., Zainal, M. K., Wahid, M. A. A., . . management. (2019). Multi method analysis for identifying the shoreline erosion during northeast monsoon season. 14(3), 43-54.

Shadmehri, T. A., Ghasemi Tousi, E., Ghassemi, S. A., Cheshomi, A., \& Alaghmand, S. (2020). A multi-criteria decision analysis approach towards efficient rainwater harvesting. Journal of Hydrology, 582.

Shanableh, A., Al-Ruzouq, R., Yilmaz, A., Siddique, M., Merabtene, T., \& Imteaz, M. (2018). Effects of land cover change on urban floods and rainwater harvesting: A case study in Sharjah, UAE. Water Water, 10(5), 631 .

Singh, L. K., Jha, M. K., \& Chowdary, V. M. (2017). Multi-criteria analysis and GIS modeling for identifying prospective water harvesting and artificial recharge sites for sustainable water supply. J. Clean. Prod. Journal of Cleaner Production, 142, 14361456.

Terêncio, D. P. S., Sanches Fernandes, L. F., Cortes, R. M. V., Moura, J. P., \& Pacheco, F. A. L. (2018). Rainwater harvesting in catchments for agro-forestry uses: A study focused on the balance between sustainability values and storage capacity. Science of The Total Environment Science of The Total Environment, 613-614, 10791092.

Thair, S. K., Mustafa, M. A., \& Ahlam, S. M. (2017). Ground water flow and water budget 
for tharthar lake. Journal of Engineering and Sustainable Development, 21(6).

Tiwari, K., Goyal, R., \& Sarkar, A. (2018). GISbased methodology for identification of suitable locations for rainwater harvesting structures. Water Resour Manage Water Resources Management: An International Journal - Published for the European Water Resources Association (EWRA), 32(5), 1811-1825.

Tupenaite, L., Lill, I., Geipele, I., \& Naimaviciene, J. (2017). Ranking of sustainability indicators for assessment of the new housing development projects: Case of the Baltic States. Resources Resources, 6(4), 55.

Varade, A. M., Khare, Y. D., Dongre, K. P., Muley, S., \& Wasnik, G. (2017). Integrated Geographical Information System (GIS)based Decision Support System (DSS) approach to identify the site-specific water conservation structures in a watershed of
Nagpur district, Central India. Sustainable Water Resources Management, 3(2), 141155. doi:10.1007/s40899-017-0085-8

Walega, A., \& Salata, T. (2019). Influence of land cover data sources on estimation of direct runoff according to SCS-CN and modified SME methods. Catena Catena, 172, 232-242.

Wu, R.-S., Molina, G. L. L., \& Hussain, F. (2018). Optimal sites identification for rainwater harvesting in Northeastern Guatemala by Analytical Hierarchy Process. Water Resour Manage Water Resources Management, 32(12), 4139-4153.

Zuidam, R. A., Zuidam-Cancelado, F. I. v., International Institute for Aerial, S., \& Earth, S. (1979). Terrain analysis and classification using aerial photographs: A geomorphological approach. AL Enschede: International Institute for Aerial Survey and Earth Sciences (ITC). 